\title{
Thermal coupled photoconductivity as a tool to understand the photothermal catalytic reduction of $\mathrm{CO}_{2}$
}

\author{
Dashuai Li †, Yu Huang †, Songmei Li ${ }^{\dagger}$, Changhua Wang*, Yingying Li, Xintong Zhang \#, Yichun Liu \\ Key Laboratory of UV-Emitting Materials and Technology of Chinese Ministry of Education, Northeast Normal University, Changchun 130024, Jilin, China
}

\section{A R T I C L E I N F O}

\section{Article history:}

Received 30 June 2019

Accepted 5 August 2019

Published 5 January 2020

\section{Keywords:}

Photoconduction

Photothermalcatalytic

Titanium dioxide

Oxygen vacancy

Carbon dioxide reduction

\begin{abstract}
A B S T R A C T
Photocatalysis shows great promise in the field of solar energy conversion. One of the reasons for this is because it promotes the development of multi-field-coupled catalysis. In order to explore the principles of multi-field-coupled catalytic reactions, an in situ multi-field-coupled characterization technique is required. In this study, we obtained hydrogenated $\mathrm{ST}-01 \mathrm{TiO}_{2}$ and observed enhanced catalytic activity by thermal coupled photocatalysis. In situ photoconductivity was employed to understand the activity enhancement. The effects of the reaction temperature, reaction atmosphere, and oxygen vacancy $(\mathrm{Ov})$ on the photoconductivity of $\mathrm{TiO}_{2}$ were studied. After coupling thermal into photoconductivity measurement, highly active $\mathrm{Ov}-\mathrm{TiO}_{2}$ displayed rapid decay of photoconductivity in a $\mathrm{CO}_{2}$ atmosphere and slow decay of photoconductivity in a $\mathrm{N}_{2}$ atmosphere. These phenomena revealed that photothermal coupling assisted the detrapping of electrons at the $0 \mathrm{v}$ surface and promoted electron transfer to $\mathrm{CO}_{2}$, which clearly explained the high photothermal catalytic activity of $\mathrm{Ov}_{-} \mathrm{TiO}_{2}$. This study demonstrated that photoconductivity is a useful tool to help understand photothermal catalytic phenomena.
\end{abstract}

(C) 2020, Dalian Institute of Chemical Physics, Chinese Academy of Sciences. Published by Elsevier B.V. All rights reserved.

\section{Introduction}

Multiple-field-coupled catalysis combined with photocatalysis is attracting increasing interest since it performs better than photocatalysis alone [1-3]. Recently, photothermal coupling has proved to be an efficient and reliable approach to improve the photocatalytic efficiency and promote the development of photothermal catalysis [4-9]. Understanding how a photothermal catalyst works requires knowledge of photocatalysis. However, present characterizations of photocatalyst systems at room temperature are insufficient to understand the effect of photothermal coupling in photothermal catalysis. In this re- gard, a photothermal coupled characterization technique is required to understand the mechanism of photothermal catalysis.

Photoconductivity measurement is a promising tool to detect photogenerated charge carriers, since a change in photocurrent is closely related to free carrier density [10]. Moreover, in situ thermal coupled photoconductivity can be easily achieved by integrating a heating unit in the photoconductivity test chamber. Pomoni et al. [11] studied the effect of temperature on the transient photoconductivity of a $\mathrm{TiO}_{2}$ film. They suggested that the transient photoconductivity of a nanocrystalline $\mathrm{TiO}_{2}$ film in vacuum was governed by the thermal re-

\footnotetext{
* Corresponding author. Tel/Fax: +86-431-85099772; E-mail: wangch100@nenu.edu.cn

\# Corresponding author. Tel/Fax: +86-431-85099772; E-mail: xtzhang@nenu.edu.cn

+ These authors contribute equally to this work.

This work was supported by the Natural Science Foundation of China (51072032, 51372036, 51102001), the Key Project of Chinese Ministry of Education (113020A), the 111 project (B13013), and Jilin Province Science and Technology Development Plan (20180101175JC, 20160520170JH). DOI: S1872-2067(19)63475-3 | http://www.sciencedirect.com/science/journal/18722067 | Chin. J. Catal., Vol. 41, No. 1, January 2020
} 
lease of electrons from the trap states in the bandgap. Liu et al. [12-14] successfully employed in situ temperature-dependent photoconductivity to understand the photocatalytic degradation of gaseous formic acid in air. They revealed that the electron transfer was determined by the interface transfer of electrons to $\mathrm{O}_{2}$ rather than by the transport. Therefore, in situ thermal coupled photoconduction can be used to study the separation, recombination, and interfacial reactions of photogenerated charges, which in turn would be useful in understanding the mechanism of photocatalysis and photothermal catalysis.

The photocatalytic activity of semiconductor oxides can be successfully enhanced by crystal facet modulation [15,16], surface modification [17], formation of Z-scheme [18] or S-scheme heterojunctions $[19,20]$, and introduction of oxygen vacancies (Ov) [21-24]. Of these methods, introduction of Ov not only extends the visible light absorption range of the semiconductor [25] but also inhibits carrier recombination [26]. Ov can also promote the adsorption of reactants and decrease the activation energy of the reaction [27]. More importantly, Ov has been found to endow the photocatalyst with photothermal catalytic activity. Thus, an Ov-type semiconductor oxide is deemed as an ideal model to study the photothermal catalytic process $[28,29]$.

In this study, the in situ thermal coupled photoconductivity of $\mathrm{Ov}-\mathrm{TiO}_{2}$ was used to correlate photoconductivity with the photothermal catalytic reduction of $\mathrm{CO}_{2}$. The effects of temperature and atmosphere on the photoconductivity were investigated to understand the photothermal catalytic of $\mathrm{CO}_{2}$ reduction. Moreover, $\mathrm{Ov}^{-\mathrm{TiO}_{2}}$ samples with different Ov contents were compared on the basis of their photoconductivity and photothermal catalytic activity to reveal the role of $\mathrm{Ov}$ in enhancing $\mathrm{CO}_{2}$ reduction. The aim of this study was to use photoconductivity to elucidate the mechanism of the photothermal catalytic reduction of $\mathrm{CO}_{2}$.

\section{Experimental}

\subsection{Preparation of $\mathrm{TiO}_{2}$ film}

To fabricate the $\mathrm{TiO}_{2}$ film, commercial ST-01 $\mathrm{TiO}_{2}$ (Japan, Ishihara Sangyo) was used to prepare a $\mathrm{TiO}_{2}$ slurry. The detailed preparation is shown in the supporting information. The $\mathrm{TiO}_{2}$ slurry was coated on fluorine-doped tin oxide (FTO) glass $(2.5 \mathrm{~cm} \times 2.5 \mathrm{~cm})$ with an etched channel $(77.52 \mu \mathrm{m} \times 2.5 \mathrm{~cm})$, followed by temperature-programmed annealing in a muffle furnace up to $500{ }^{\circ} \mathrm{C}$. The $\mathrm{TiO}_{2}$ film was then heated in a $\mathrm{N}_{2} / \mathrm{H}_{2}$ atmosphere $\left(10 \% \mathrm{H}_{2}, 90 \% \mathrm{~N}_{2}\right)$ at 150 and $350{ }^{\circ} \mathrm{C}$, respectively. This was denoted as $\mathrm{H}_{2}-150$ and $\mathrm{H}_{2}-350$ respectively. The $\mathrm{TiO}_{2}$ film without the $\mathrm{N}_{2} / \mathrm{H}_{2}$ treatment was denoted as "Unannealed."

\subsection{Photoconductivity test}

Scheme 1 shows the device structure used for the photoconductivity measurements. The test chamber was connected to an electrochemical workstation (Keithley 2400

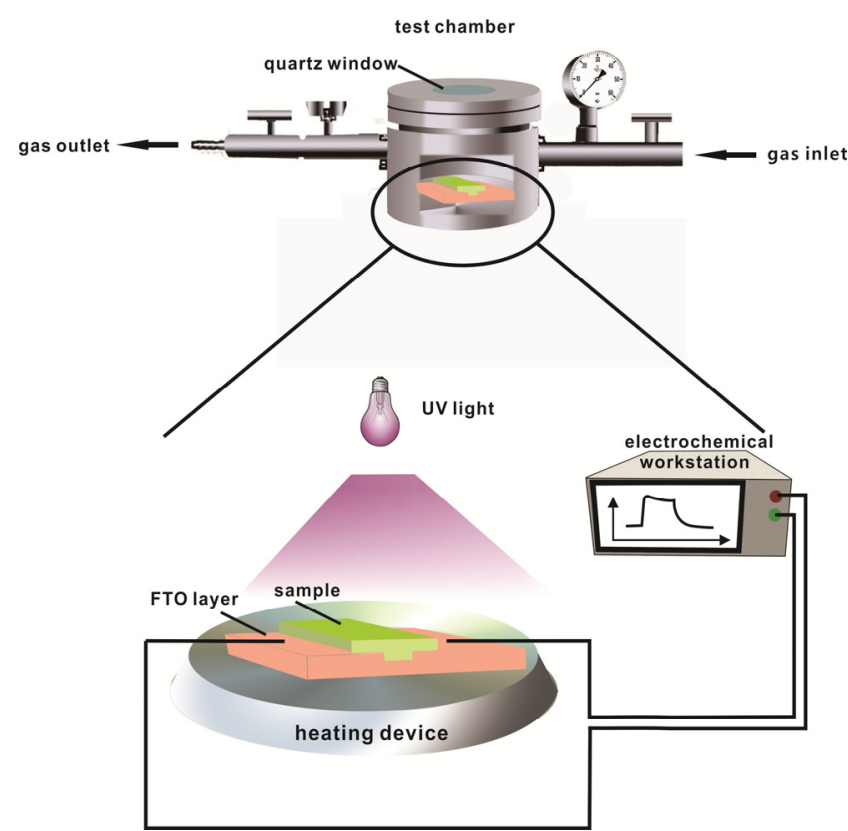

Scheme 1. Schematic illustration of the device structure used for photoconductivity measurements.

Sourcemeter), which was used to observe the changes in photocurrent. A heating plate was integrated at the bottom of the chamber, and the temperature was controlled using a thermocouple. The chamber contained shielded wires connected to an external electrochemical workstation for the accurate measurement of photoconductivity. UV light (Hayashi LA-410UV lamp) was irradiated through a circular quartz window (diameter, $4.5 \mathrm{~cm}$ ) from the top of the chamber, with a light intensity of $20 \mathrm{~mW} / \mathrm{cm}^{2}$.

Before the measurements, the chamber was pre-aerated by $\mathrm{CO}_{2}$ or $\mathrm{N}_{2}$ for $20 \mathrm{~min}$ to remove the air in the reactor. The flow rate of the gases was controlled by a digital gas mass flow meter and maintained at $2 \mathrm{~L} / \mathrm{min}$. Each set of measurements was commenced in a dark state for 0 to $20 \mathrm{~s}$. The UV light source was then switched on at $20 \mathrm{~s}$ and turned off at $100 \mathrm{~s}$. The measurements were conducted at room temperature and 120 ${ }^{\circ} \mathrm{C}$, respectively. The temperature of the different samples was monitored by an infrared camera. The infrared thermograms of the Unannealed, $\mathrm{H}_{2}-150$, and $\mathrm{H}_{2}-350$ samples are shown in figure $\mathrm{S} 1$. As can be seen, the temperature changes in the samples were primarily due to the heating of the external hot plate, while the irradiation of the external light resulted in only a small additional increase in temperature.

The photocurrent was measured and defined using the following formula [14]:

$$
j=U \sigma A / L
$$

Here, $\mathrm{U}$ is the voltage applied by an electrochemical workstation, $\sigma$ is the conductivity, $\mathrm{L}$ is the channel width, and $\mathrm{A}$ is the cross-sectional area of the $\mathrm{TiO}_{2}$ film. The applied voltage, $\mathrm{U}$, was set at $1.5 \mathrm{~V}$. Since the photocurrent is proportional to conductivity, the change regularity of photocurrent represents a change in conductivity. Hence, the photocurrent is directly used 
and not converted to photoconductivity.

\subsection{Photocatalytic and photothermal catalytic reduction of $\mathrm{CO}_{2}$}

In the photocatalytic test, ST-01 film was put into an airtight reactor. After sealing the reactor, carbon dioxide gas was bubbled for $20 \mathrm{~min}$ to expel the air from the reactor $(2 \mathrm{~L} / \mathrm{min})$. The film was then irradiated by $20 \mathrm{~mW} / \mathrm{cm}^{2}$ UV light for $3 \mathrm{~h}$. A Shimadzu 2400 gas chromatograph was used to measure the yield of CO.

The photothermal catalytic experiment was similar to the above photocatalytic experiment. The schematic of the reactor is shown in Scheme 2. The difference between the two setups was that in the photothermal catalytic process, external heating was applied and the temperature was controlled at $120^{\circ} \mathrm{C}$.

\section{Results and discussion}

It is well reported that ST-01 is composed of an anatase phase $[30,31]$. During the preparation of the $\mathrm{TiO}_{2}$ slurry and the $\mathrm{N}_{2} / \mathrm{H}_{2}$ treatment, no significant structural changes in $\mathrm{TiO}_{2}$ were observed in the X-ray diffraction (XRD) patterns (Fig. S2) as well as in the UV/vis spectra (Fig. 1(a)) and Raman spectra (Fig. 1(b)). However, electron spin resonance spectroscopy (ESR) (Fig. 1(c)) was able to distinguish three typical samples. The sample after hydrogen annealing showed a distinct signal at $g=2.002$, where a higher annealing temperature led to a stronger signal. The signal at $g=2.002$ is a characteristic feature of the $\mathrm{O}_{2}$ - radicals generated from the interaction of the absorbed atmospheric $\mathrm{O}_{2}$ with the surface $\mathrm{Ov}$ sites [21,22,32-34]. Therefore, Ov was successfully introduced into the $\mathrm{H}_{2}-150$ and $\mathrm{H}_{2}-350$ samples. Yan et al. [35] also proposed that a vacuum or a reducing atmosphere could produce $\mathrm{Ov}$, which is consistent with our results. Integral processing on the ESR signals was performed to compare the Ov in different samples quantitively. The number of spin electrons over the Unan- nealed, $\mathrm{H}_{2}-150$, and $\mathrm{H}_{2}-350$ samples were $5.3 \times 10^{-9}, 1.11 \times 10^{-8}$, and $3.24 \times 10^{-8} \mathrm{~mol} / \mathrm{g}$, respectively. Assuming that all spin electrons originated from $\mathrm{Ov}$, the ratio of $\mathrm{Ov}$ concentration for the Unannealed, $\mathrm{H}_{2}-150$, and $\mathrm{H}_{2}-350$ samples was found to be 1 : $2.08: 6.09$.

Fig. 2 shows the catalytic reduction of $\mathrm{CO}_{2}$ via photocatalysis and photothermal catalysis, respectively. It was observed that $\mathrm{CO}$ was the sole product, and no $\mathrm{CH}_{4}$ was produced. This agrees with most reported results that a cocatalyst-free $\mathrm{TiO}_{2}$ system is not suitable for $\mathrm{CH}_{4}$ production due to the difficulty of multiple electron/proton transfer [36-40]. By carefully comparing CO yields, several interesting conclusions can be drawn. Firstly, thermal coupled photocatalysis for all samples significantly improved the CO yield in comparison with photocatalysis, suggesting that photothermal coupling is a powerful tool for enhancing $\mathrm{CO}_{2}$ reduction with a photocatalyst. Secondly, for photocatalysis, the introduction of $\mathrm{Ov}$, unfortunately, brings a lower $\mathrm{CO}$ yield, with the $\mathrm{H}_{2}-150$ sample giving the lowest $\mathrm{CO}$ yield. This suggests that $\mathrm{Ov}$ is not conducive to enhanced photocatalysis. Contrary to this finding, the introduction of Ov enhances the $\mathrm{CO}$ yield for photothermal catalysis, with the $\mathrm{H}_{2}-150$ sample providing the highest $\mathrm{CO}$ yield. There is no significant activity loss after four experimental runs (Fig. S3), which suggests that Ov is suitable for enhanced photothermal catalysis. Thus, photothermal catalysis was found to be superior to photocatalysis with regards to $\mathrm{CO}_{2}$ reduction, and $\mathrm{Ov}$ was found to improve the activity of $\mathrm{TiO}_{2}$ in photothermal catalysis.

As was discussed, in the photocatalytic reduction of $\mathrm{CO}_{2}, \mathrm{Ov}$ helps adsorption of $\mathrm{CO}_{2}$ and enhances $\mathrm{CO}$ yield. The $\mathrm{CO}_{2}$ adsorption behavior for hydrogenated $\mathrm{TiO}_{2}$ was then investigated. Fig. S4 shows that the $\mathrm{CO}_{2}$ adsorption ability follows the order: $\mathrm{H}_{2}-350>\mathrm{H}_{2}-150$. However, the photothermal catalytic activity of $\mathrm{H}_{2}-350$ is lower than that of $\mathrm{H}_{2}-150$. Thus, it can be deduced that the photothermal catalytic activity is not solely governed by $\mathrm{CO}_{2}$ adsorption.

To investigate the causes for the enhanced activity of pho-

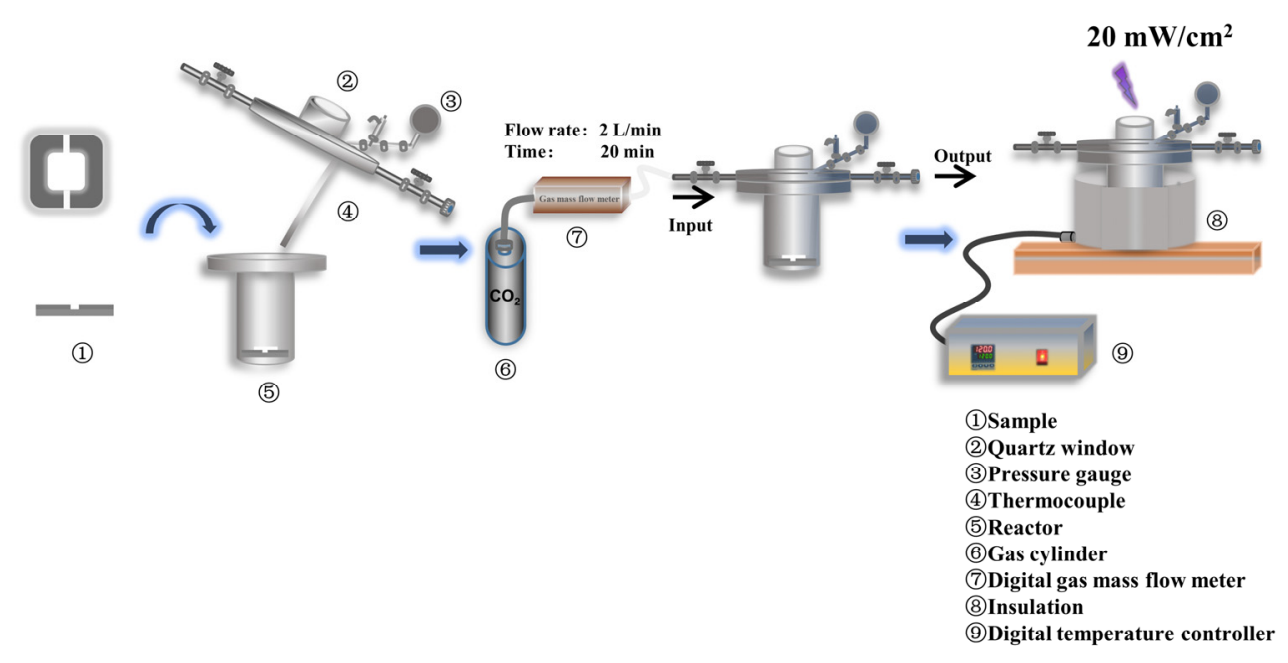

Scheme 2. Schematic illustration of the reactor used for the photothermal catalytic reduction of $\mathrm{CO}_{2}$. 

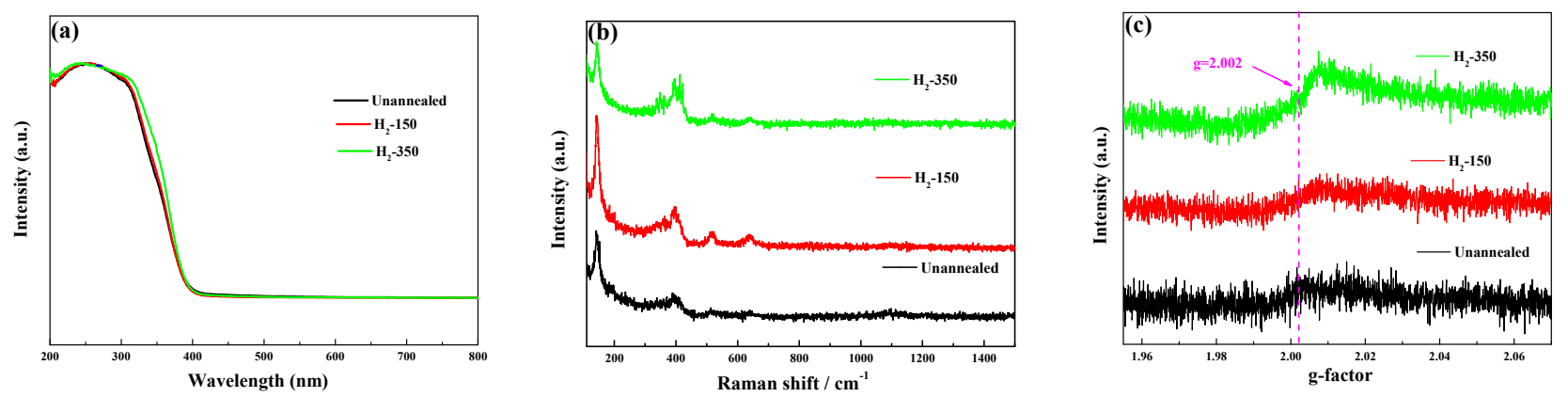

Fig. 1. UV-vis spectra (a), Raman spectra (b), and ESR spectra (c) of the samples with different annealing temperatures.

tothermal coupling and Ov, photoconductivity measurements at different conditions were performed. When comparing the photoconductivity at room temperature and $120{ }^{\circ} \mathrm{C}$ (Fig. 3, inset), it was found that all samples exhibit higher photoconductivity at $120^{\circ} \mathrm{C}$. The increased photoconductivity is believed to result from the accelerated transfer of electrons from the bulk to the surface at elevated temperatures. Due to the increased number of electrons at the surface per unit time, the probability of electron/proton-coupled reduction of $\mathrm{CO}_{2}$ is enhanced. This is consistent with the enhanced activity observed in photothermal catalysis that is not seen in photocatalysis (Fig. 2).

The decay of photoconductivity on the photoconductivity curve can provide valuable information. As shown in Fig. 3(a) and (b), both unannealed and $\mathrm{H}_{2}-150$ samples displayed an accelerated decay with the increase in temperature in ${\mathrm{a} \mathrm{CO}_{2}}$ atmosphere. In principle, the decay of photoconductivity is induced by either charge recombination or a charge-involved surface reaction. Since the photoconductivity is measured in $\mathrm{CO}_{2}$, the photogenerated electrons tend to be captured by $\mathrm{CO}_{2}$, which partly contributes to decreased photoconductivity. In this regard, the accelerated decay means a higher capacity for $\mathrm{CO}_{2}$ reduction with a catalyst at higher temperatures. There-

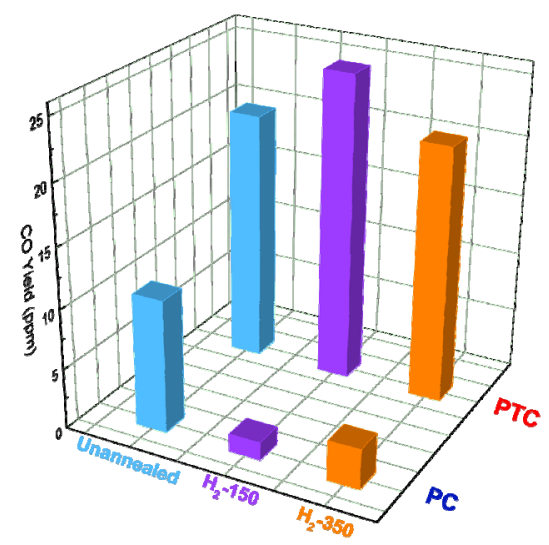

Fig. 2. CO yield obtained from the carbon dioxide reduction of different samples, with a UV light intensity of $20 \mathrm{~mW} / \mathrm{cm}^{2}$, PC refers to photocatalysis carried out at room temperature, and PTC refers to photothermal catalysis carried out at $120^{\circ} \mathrm{C}$. fore, the Unannealed and $\mathrm{H}_{2}-150$ samples have great potential to be activated at $120{ }^{\circ} \mathrm{C}$. However, the $\mathrm{H}_{2}-350$ sample displays a slower decay at elevated temperatures, as shown in Fig. 3(c). It is due to the structural difference between the $\mathrm{H}_{2}-350$ sample and the Unannealed and $\mathrm{H}_{2}-150$ samples that a higher content of $\mathrm{Ov}$ is present in $\mathrm{H}_{2}-350$ [41-43]. When considering the energy required for electron detrapping from the defect state to the conduction band by thermal excitation, the electrons trapped at a shallow level rather than a deep level are most likely to be excited to the conduction band [44-46]. It is well known that $\mathrm{CO}_{2}$ reduction is a multi-electron reduction process. The electrons located at the conduction band of $\mathrm{TiO}_{2}$ are thermodynamically allowed to reduce $\mathrm{CO}_{2}$ to $\mathrm{CO}$. However, the electrons trapped at a deep level are unlikely to participate in $\mathrm{CO}_{2}$ reduction due to them being in lower energy state than that required for $\mathrm{CO}$ production. Therefore, the slower decay of photoconductivity in $\mathrm{H}_{2}-350$ is believed to partly result from the weaker reduction ability of the electrons at a deep energy level. The results are consistent with the enhanced activity in the photothermal catalysis results of $\mathrm{H}_{2}-150$ as compared to the photothermal catalysis results of $\mathrm{H}_{2}-350$ in Fig. 2. A sample of $\mathrm{H}_{2}-550$ was also prepared, and its photoconductivity was measured (Fig. S5). The decay trend of the photoconductivity of $\mathrm{H}_{2}-550$ under the atmosphere of $\mathrm{CO}_{2}$ and $\mathrm{N}_{2}$ was the same as that of $\mathrm{H}_{2}-350$. Hence, $\mathrm{H}_{2}-350$ was regarded as a standard sample with a high concentration of $\mathrm{Ov}$ for a photoconductivity study.

To further prove that the faster decay of photoconductivity results from the catalytic reduction of $\mathrm{CO}_{2}$ rather than charge recombination, photoconductivity measurements under a $\mathrm{N}_{2}$ atmosphere was performed. As shown in Fig. 4, the decay of thermal coupled photoconductivity of the $\mathrm{H}_{2}-150$ and the $\mathrm{H}_{2}-350$ samples was slower in a $\mathrm{N}_{2}$ atmosphere compared to a $\mathrm{CO}_{2}$ atmosphere. The $\mathrm{H}_{2}-150$ sample, in particular, shows a significant difference in the decay of photoconductivity under $\mathrm{CO}_{2}$ as compared to the $\mathrm{N}_{2}$ atmosphere. However, this slower decay of photoconductivity under a $\mathrm{N}_{2}$ atmosphere is not observed for unannealed $\mathrm{TiO}_{2}$. The mechanism diagram for this is shown in Scheme S1. According to the analysis of the changes in photoconductivity in the $\mathrm{CO}_{2}$ atmosphere and $\mathrm{N}_{2}$ atmosphere, the results can be interpreted in two ways. On the one hand, the charge recombination of the $\mathrm{H}_{2}-150$ sample and the $\mathrm{H}_{2}-350$ sample does not decrease upon thermal activation, 

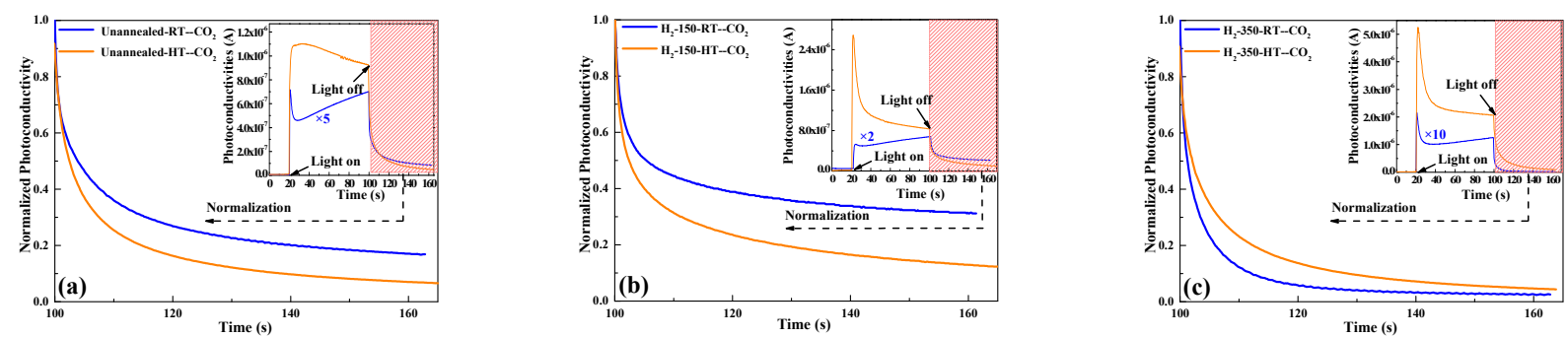

Fig. 3. The normalized photoconductivity response after the UV light was switched off at RT (blue line, RT refers to room temperature) and HT (orange line, $\mathrm{HT}$ refers to $120^{\circ} \mathrm{C}$ ), in a carbon dioxide atmosphere. (a) Unannealed sample; (b) $\mathrm{H}_{2}-150$ sample; (c) $\mathrm{H}_{2}-350$ sample. The dynamic change of the actual conductivity in a carbon dioxide atmosphere is given as an inset.
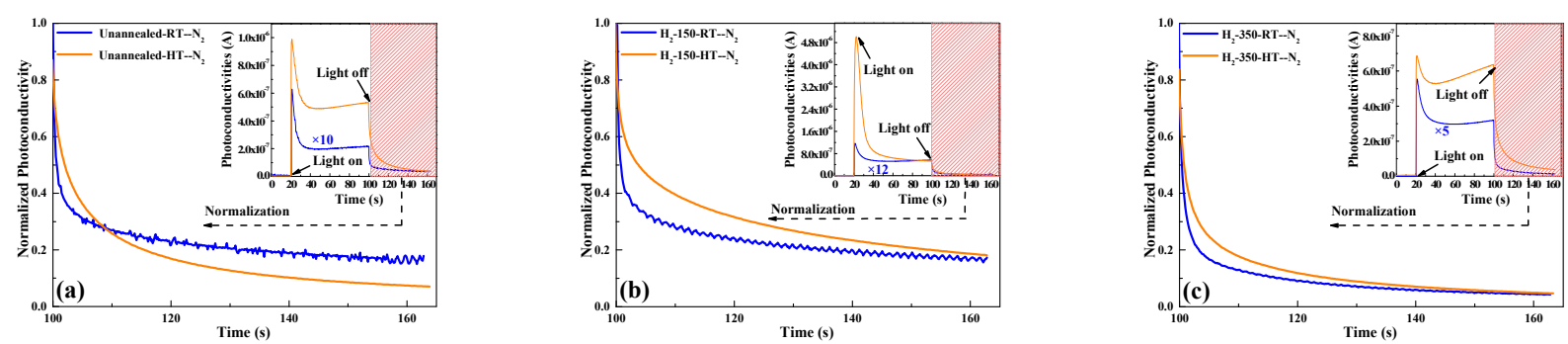

Fig. 4. The normalized photoconductivity response after the UV light was switched off at RT (blue line, RT refers to room temperature) and HT (orange line, $\mathrm{HT}$ refers to $120^{\circ} \mathrm{C}$ ), in a $\mathrm{N}_{2}$ atmosphere. (a) Unannealed sample; (b) $\mathrm{H}_{2}-150$ sample; (c) $\mathrm{H}_{2}-350$ sample. The dynamic change in conductivity in the $\mathrm{N}_{2}$ atmosphere is given as an inset.

since it benefits from the introduction of Ov. On the other hand, the photogenerated electrons trapped by Ov can be released to the conduction band. This detrapping of electrons can accelerate surface reactions.

Several conclusions can be drawn above from the photoconductivity test: (1) Thermal coupled photoconductivity is higher than room-temperature photoconductivity for the unannealed $\mathrm{TiO}_{2}$ and $\mathrm{Ov}-\mathrm{TiO}_{2}$; (2) The accelerated decay of photoconductivity for $\mathrm{Ov}-\mathrm{TiO}_{2}$ in the simulated photothermal reaction implies a promoted charge-involved surface reaction; (3) The slower decay of photoconductivity for $\mathrm{Ov}_{-} \mathrm{TiO}_{2}$ implies thermal detrapping of electrons at Ov.

To correlate thermal coupled photoconductivity with photothermal catalysis, the mechanism shown in Scheme 3 was proposed. Upon photoexcitation, the electrons of the valence band can be excited to the conduction band or trapped by shallow Ov located below the conduction band. The surface adsorbed $\mathrm{CO}_{2}$ can be reduced by coupled electrons/protons. At this stage, the thermal coupled photoconductivity was increased in comparison to room temperature photoconductivity, due to the combined contribution of photo-induced excitation and thermal-induced detrapping of electrons. When the UV light is switched off, the trapped electrons at Ov gradually recombine with nearby holes at room temperature. The stored electrons seldom transfer to the surface and participate in $\mathrm{CO}_{2}$ reduction, which leads to a slow electron consumption rate by $\mathrm{CO}_{2}$. Therefore, a slower decay of photoconductivity is observed. At a higher temperature, the trapped electrons at $\mathrm{Ov}$ tend to escape to the conduction band and are then transferred to the surface, which leads to a faster electron consumption rate by $\mathrm{CO}_{2}$. Hence, a faster decay of photoconductivity is observed.

\section{Conclusions}

In summary, thermal coupled photoconductivity was meas-

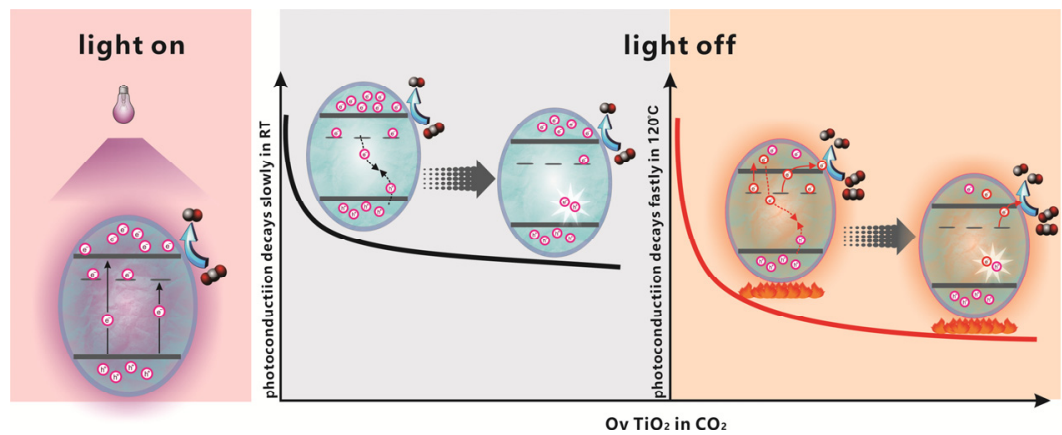

Scheme 3. Schematic illustration of the thermal coupled photoconductivity of $\mathrm{Ov}_{-} \mathrm{TiO}_{2}$ in $\mathrm{CO}_{2}$, $(\mathrm{RT}$ refers to room temperature). 
ured to obtain an understanding of the photothermal catalytic reduction of $\mathrm{CO}_{2}$. Photothermal catalysis shows that the introduction of Ov can significantly enhance the CO yield over $\mathrm{Ov}-\mathrm{TiO}_{2}$. In comparison to room temperature photoconductivity, thermal coupled photoconductivity of highly active $\mathrm{Ov}-\mathrm{TiO}_{2}$ exhibits an accelerated decay in a $\mathrm{CO}_{2}$ atmosphere and a decelerated decay in a $\mathrm{N}_{2}$ atmosphere. With regards to the correlation between thermal coupled photoconductivity and photothermal catalysis, an accelerated electron transfer to $\mathrm{CO}_{2}$ and the detrapping of electrons to the conduction band of $\mathrm{TiO}_{2}$ are confirmed, which provides a reasonable explanation for the superior performance of $\mathrm{Ov}^{-} \mathrm{TiO}_{2}$ in photothermal catalysis. This study on thermal coupled photoconductivity could represent a promising method for understanding photothermal catalysis.

\section{References}

[1] Z. F. Jiang, H. L. Sun, T. Q. Wang, B. Wang, W. Wei, H. M. Li, S. Q. Yuan, T. C. An, H. J. Zhao, J. G. Yu, P. K. Wong, Energy Environ. Sci., 2018, 11, 2382-2389.

[2] K. K. Paul, N. Sreekanth, R. K. Biroju, A. J. Pattison, D. Escalera-Lopez, A. Guha, T. N. Narayanan, N. V. Rees, W. Theisc, P. K. Giri, J. Mater. Chem. A, 2018, 6, 22681-22696.

[3] J. Ren, S. X. Ouyang, H. Xu, X. G. Meng, T. Wang, D. F. Wang, J. H. Ye, Adv. Energy Mater., 2017, 7, 1601657.

[4] J. X. Low, L. Y. Zhang, B. C. Zhu, Z. Y. Liu, J. G. Yu, ACS Sustainable Chem. Eng., 2018, 6, 15653-15661.

[5] L. Zhang, G. G. Kong, Y. P. Meng, J. S. Tian, L. J. Zhang, S. L. Wan, J. D. Lin, Y. Wang, ChemSusChem, 2017, 10, 4709-4714.

[6] L. Wang, Y. Wang, Y. Cheng, Z. Liu, Q. Guo, M. N. Ha, Z. Zhao, J. Mater. Chem. A, 2016, 4, 5314-5322.

[7] B. Liu, X. Zhao, C. Terashima, A. Fujishima, K. Nakata, Phys. Chem. Chem. Phys., 2014, 16, 8751-8760.

[8] G. Chen, R. Gao, Y. Zhao, Z. Li, G. I. N. Waterhouse, R. Shi, J. Zhao, M. Zhang, L. Shang, G. Sheng, X. Zhang, X. Wen, L. Z. Wu, C. H. Tung, T. Zhang, Adv. Mater., 2018, 30, 1704663.

[9] W. Zhang, L. Wang, K. Wang, M. U. Khan, M. Wang, H. Li, J. Zeng, Small, 2017, 13, 201602583.
[10] J. Nelson, A. M. Eppler, I. M. Ballard, J. Photochem. Photobiol. A, 2002, 148, 25-31.

[11] K. Pomonia, A. Vomvas, C. Trapalib, Thin Solid Films, 2005, 479, 160-165.

[12] B. S. Liu, X. L. Wang, L. P. Wen, X. J. Zhao, Chem. Eur. J., 2013, 19, 10751-10759.

[13] J. J. Yang, B. S. Liu, H. Xie, X. J. Zhao, C. Terashima, A. Fujishima, K. Nakata, J. Phys. Chem. C, 2015, 119, 21711-21722.

[14] B. S. Liu, J. J. Yang, X. J. Zhao, J. G. Yu, Phys. Chem. Chem. Phys., 2017, 19, 8866-8873.

[15] J. Y. Wang, B. S. Liu, K. Nakata, Chin. J. Catal., 2019, 40, 403-412.

[16] Y. A. Zhu, Z. Y. Zhang, N. Lu, R. N. Hua, B. Dong, Chin. J. Catal., 2019, 40, 413-423.

[17] J. X. Low, B. Cheng, J. G. Yu, Appl. Surf. Sci., 2017, 392, 658-686.

[18] J. X. Low, B. Z. Dai, T. Tong, C. J. Jiang, J. G. Yu, Adv. Mater., 2019, 31, 1802981

[19] J. W. Fu, Q. L. Xu, J. X. Low, C. J. Jiang, J. G. Yu, Appl. Catal. B, 2019, 243, 556-565

[20] M. Edelmannová, K. Y. Lin, J. C. S. Wu, I. Troppová, L. Čapek, K. Kočí, Appl. Surf. Sci., 2018, 454, 313-318.

[21] L. N. Kong, Z. Q. Jiang, C. H. Wang, F. X. Wan, Y. Y. Li, L. Z. Wu, J. F. Zhi, X. T. Zhang, S. J. Chen, Y. C. Liu, ACS Appl. Mater. Inter., 2015, 7, 7752-7758.

[22] L. N. Kong, C. H. Wang, F. X. Wan, H. Zheng, X. T. Zhang, Appl. Surf. Sci., 2017, 396, 26-35

[23] A. Nikokavoura, C. Trapalis, Appl. Surf. Sci., 2017, 391, 149-174.

[24] K. Z. Qi, S. Y. Liu, M. Qiu, Chin. J. Catal., 2018, 39, 867-875.

[25] T. Wang, W. W. Li, D. D. Xu, X. M. Wu, L. W. Cao, J. X. Meng, Chin. J. Catal., 2017, 38, 1184-1195.

[26] L. Li, P. Li, Y. J. Wang, L. Lin, A. H. Shah, T. He, Appl. Surf. Sci., 2018, 452, 498-506.

[27] Y. Sohn, W. X. Huang, F. Taghipour, Appl. Surf. Sci., 2017, 396, 1696-1711.

[28] X. B. Li, J. Xiong, Y. Xu, Z. J. Feng, J. T. Huang, Chin. J. Catal., 2019, 40, 424-433.

[29] X. B. Li, J. Xiong, X. M. Gao, J. T. Huang, Z. J. Feng, Z. Chen, Y. F. Zhu, J. Alloys Compd., 2019, 802, 196-209.

[30] S. Moziaa, A. W. Morawski, M. Toyoda, M. Inagaki, Sep. Purif. Technol., 2008, 63, 386-391.

[31] P. H. Wen, H. Itoh, W. P. Tang, Q. Feng, Langmuir, 2007, 23, 11782-11790.

\section{Graphical Abstract}

Chin. J. Catal., 2020, 41: 154-160 doi: S1872-2067(19)63475-3

\section{Thermal coupled photoconductivity as a tool to understand the photothermal catalytic reduction of $\mathrm{CO}_{2}$}

Dashuai Li, Yu Huang, Songmei Li, Changhua Wang*, Yingying Li, Xintong Zhang*, Yichun Liu

Northeast Normal University

By correlating thermal coupled photoconductivity with photothermal catalysis, accelerated electron transfer to $\mathrm{CO}_{2}$ and detrapping of electrons to conduction band of $\mathrm{TiO}_{2}$ are confirmed, and this provides a clear explanation for the superior performance of $\mathrm{Ov}_{-} \mathrm{TiO}_{2}$ in photothermal catalysis.

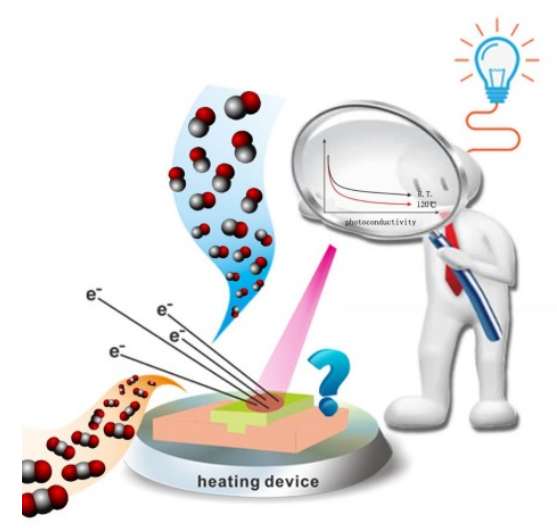


[32] K. Komaguchi, T. Maruoka, H. Nakano, I. Imae, Y. Oyama, Y. Harima, J. Phys. Chem. C, 2010, 114, 1240-245

[33] I. Nakamura, N. Negishi, S. Kutsuna, T. Ihara, S. Sugihara, K. Takeuchi, J. Mol. Catal. A, 2000, 161, 205-212.

[34] S. H. Wei, S. Ni, X. X. Xu, Chin. J. Catal., 2018, 39, 510-516.

[35] H. Yu, S. C. Yan, P. Zhou, Z. G. Zou, Appl. Surf. Sci., 2018, 427, 603-607.

[36] Y. Y. Li, C. H. Wang, M. Song, D. S. Li, X. T. Zhang, Y. C. Liu, Appl. Catal, B, 2019, 243, 760-770.

[37] X. Y. Liu, M. Ye, S. P. Zhang, G. C. Huang, C. H. Li, J. G. Yu, P. K. Wong, S. W. Liu, J. Mater. Chem. A, 2018, 6, 24245-24255.

[38] A. Y. Meng, L.Y. Zhang, B. Cheng, J. G. Yu, ACS Appl. Mater. Interfaces, 2019, 11, 5581-5589.

[39] T. Yui, A. Kan, C. Saitoh, K. Koike, T. Ibusuki, O. Ishitani, ACS Appl.
Mater. Interfaces, 2011, 3, 2594-2600.

[40] X. G. Meng, T. Wang, L. Q. Liu, S. X. Ouyang, P. Li, H. L. Hu, T. Kako, H. Iwai, A. Tanaka, J. H. Ye, Angew. Chem. Int. Ed., 2014, 53, 11478-11482.

[41] L. C. Wang, Y. Wang, Y. Cheng, Z. F. Liu, Q. S. Guo, M. N. Ha, Z. Zhao, J. Mater. Chem. A., 2016, 4, 5314-5322.

[42] X. B. Chen, L. Liu, P. Y. Yu, S. S. Mao, Science, 2011, 331, 746-750.

[43] G. B. Zhang, T. F. Xiong, M. Y. Yan, L. He, X. B. Liao, C. Q. He, C. S. Yin, H. N. Zhang, L. Q. Mai, Nano Energy, 2018, 49, 555-563.

[44] J. C. Bourgoin, M. Zazoui, Phys. Rev. B, 1992, 45, 11324.

[45] P. Ščajev, S. Miasojedovas, L. Subačius, K. JarašiūnaS, A. V. Mazanik, O. V. Korolik, M. Kato, J. Lumin., 2019, 212, 92-98.

[46] L. L. Hou, Z. J. Guan, M. Zhang, C. Q. He, Q. Y. Li, J. J. Yang, Catal. Sci. Technol., 2018, 8, 2809-2817.

\title{
利用光热耦合下的光电导研究 $\mathrm{TiO}_{2}$ 光热催化还原 $\mathrm{CO}_{2}$
}

\author{
李大帅 ${ }^{\dagger}$, 黄 誉 ${ }^{\dagger}$, 李松美 ${ }^{\dagger}$, 王长华*, 李莹莹, 张昕制, 刘益春 \\ 东北师范大学紫外光发射材料与技术教育部重点实验室, 吉林长春130024
}

摘要: 利用太阳能缓解能源危机和解决环境污染, 是当前和未来的全球性课题. 其中, 光催化技术的研究步伐日渐加快. 这不仅体现在光催化材料种类的增加, 更体现在以光催化为基础的多场协同催化, 特别是光热耦合作用成为增强光催化性 能的一种高效、可靠的方法. 氧空位的引入不仅可以拓宽催化剂对可见光的吸收、抑制载流子的复合、促进反应物的吸 附以及降低反应的活化能, 而且对于光热协同催化效率的提升有着重要的贡献. 然而, 目前光热协同催化的表征多局限于 常规的光催化手段. 开展光热耦合下的测量技术对深刻理解光热催化是十分必要的. 本文研究温度、气氛、氧空位浓度对 $\mathrm{TiO}_{2}$ 光电导的影响, 构建光电导与光热催化活性之间的关系.

我们将商用的ST-01 $\mathrm{TiO}_{2}$ 制成浆料, 利用丝网印刷法将浆料覆盖在刻有沟槽的FTO上, 并通过 $\mathrm{N}_{2} / \mathrm{H}_{2}$ 混合气不同温度退 火, 得到不同氧空位含量的 $\mathrm{TiO}_{2}$ 薄膜 $\left(\mathrm{Ov}-\mathrm{TiO}_{2}\right)$. 采用紫外-可见光谱(UV-Vis), 拉曼光谱(Raman), 电子顺磁共振( $\left.\mathrm{ESR}\right)$ 等手 段对样品进行了表征. 结果表明, $\mathrm{N}_{2} / \mathrm{H}_{2}$ 退火温度越高, 氧空位浓度越高.

我们对不同浓度氧空位的样品进行了光催化及光热协同催化 $\mathrm{CO}_{2}$ 还原实验. 结果表明, 适量氧空位的样品 $\left(\mathrm{H}_{2}-150\right)$ 光 催化还原 $\mathrm{CO}_{2}$ 性能最差, 但光热协同催化还原 $\mathrm{CO}_{2}$ 的性能最佳. 我们对其光电导值的衰减情况进行了分析, 看到 $\mathrm{H}_{2}-150$ 样品 在 $\mathrm{CO}_{2}$ 气氛、光热条件下, 电导衰减加快. 由于光电导的衰减是由电荷复合和电荷参与的表面反应共同决定的, 为确定是哪 一因素决定了电导的衰减, 我们进一步测试了 $\mathrm{H}_{2}-150$ 样品在 $\mathrm{N}_{2}$ 气氛下的电导衰减情况. 结果发现, $\mathrm{H}_{2}-150$ 样品在 $\mathrm{N}_{2}$ 气氛、光 热条件下电导衰减反而变慢. 这表明, 造成 $\mathrm{H}_{2}-150$ 样品在 $\mathrm{CO}_{2}$ 气氛、光热条件下的电导衰减加快是光热条件下 $\mathrm{CO}_{2}$ 还原速率 加快, 也验证了 $\mathrm{H}_{2}-150$ 具有较好的光热催化 $\mathrm{CO}_{2}$ 活性. 与 $\mathrm{H}_{2}-150$ 样品不同的是, 大量氧空位样品 $\left(\mathrm{H}_{2}-350\right)$ 在 $\mathrm{CO}_{2}$ 气氛、光热条 件下电导衰减反而变慢, 我们认为这是由于 $\mathrm{H}_{2}-350$ 存在深能级缺陷, 在热的作用下会将捕获的电子释放, 因此延缓了光电 导的衰减. 但由于深能级电子的还原能力较弱, 所以 $\mathrm{H}_{2}-350$ 样品的光热 $\mathrm{CO}_{2}$ 还原活性稍逊于 $\mathrm{H}_{2}-150$.

综上所述, 在光热电导与光热催化相关的研究中, 我们证实了在Ov- $\mathrm{TiO}_{2}$ 中被捕获的电子在热激发下可再次向导带弛 豫, 从而解释了 $\mathrm{Ov}-\mathrm{TiO}_{2}$ 优异的光热催化性能. 因此, 光热电导的研究在理解光热催化方面具有重要的前景.

关键词: 光电导; 光热协同催化; 二氧化钣; 氧空位; 二氧化碳还原

收稿日期: 2019-06-30. 接受日期: 2019-08-05. 出版日期: 2020-01-05.

*通讯联系人. 电话/传真: (0431)85099772; 电子信箱: wangch100@nenu.edu.cn

\#通讯联系人. 电话/传真: (0431)85099772; 电子信箱: xtzhang@nenu.edu.cn

†共同第一作者.

基金来源：本课题由国家自然科学基金(51072032，51372036，51102001); 教育部重点项目(113020A); 111项目(B13013); 吉林省 科技发展规划(20180101175JC, 20160520170JH).

本文的电子版全文由Elsevier出版社在ScienceDirect上出版(http://www.sciencedirect.com/science/journal/18722067). 